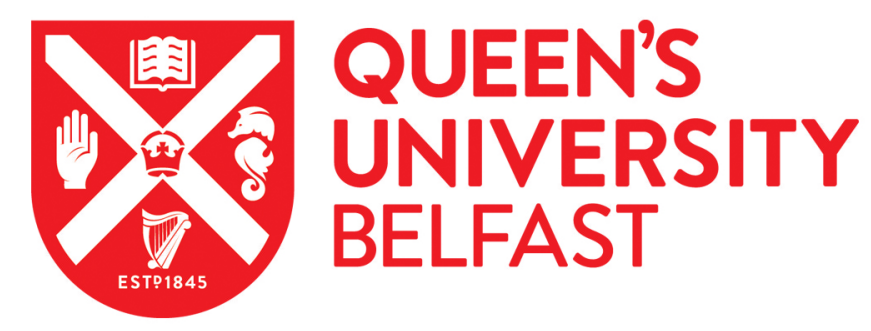

\title{
Impact of institutional pressures on organizational citizenship behaviors for the environment: Evidence from megaprojects
}

Wang, G., He, Q., Xia, B., Meng, X., \& Wu, P. (2018). Impact of institutional pressures on organizational citizenship behaviors for the environment: Evidence from megaprojects. Journal of Management in Engineering, 34(5), 1-11. [04018028]. https://doi.org/10.1061/(ASCE)ME.1943-5479.0000628

Published in:

Journal of Management in Engineering

Document Version:

Peer reviewed version

Queen's University Belfast - Research Portal:

Link to publication record in Queen's University Belfast Research Portal

Publisher rights

(C) 2018 American Society of Civil Engineers.

This work is made available online in accordance with the publisher's policies. Please refer to any applicable terms of use of the publisher.

\section{General rights}

Copyright for the publications made accessible via the Queen's University Belfast Research Portal is retained by the author(s) and / or other copyright owners and it is a condition of accessing these publications that users recognise and abide by the legal requirements associated with these rights.

Take down policy

The Research Portal is Queen's institutional repository that provides access to Queen's research output. Every effort has been made to ensure that content in the Research Portal does not infringe any person's rights, or applicable UK laws. If you discover content in the Research Portal that you believe breaches copyright or violates any law, please contact openaccess@qub.ac.uk. 
1 Investigating the Impact of Institutional Pressures on Organizational Citizenship

\section{Abstract}

5 A brisk building boom of megaprojects leads to a wide range of environmental problems, particularly in developing countries such as China. To prevent environmental problems effectively, megaprojects require proactive environmental initiatives that are based on individual, voluntary, and discretionary behaviors - also known as organizational citizenship

9 behaviors for the environment (OCBEs). OCBEs (e.g., sharing knowledge to prevent

10 pollution and making suggestions to minimize waste) play an important role in improving

11 megaproject environmental performance. However, this line of research is still in its infancy

12 and the institutional-psychological mechanism leading megaproject practitioners to engage in

13 OCBEs is largely unexplored. To fill this gap, this paper presents an individual-level analysis

14 that investigates how institutional pressures impact project practitioners' OCBEs according to

\footnotetext{
${ }^{1}$ Lecturer, College of Public Administration, Huazhong Agricultural University, 1 Shizishan Street, Wuhan, 430070, China. E-mail: ge_wang@yeah.net

2 Professor, Research Institute of Complex Engineering \& Management, School of Economics and Management, Tongji University, 1500 Siping Road, Shanghai, 200092, China (corresponding author). E-mail: heqinghua@263.net

${ }^{3}$ Associate Professor, School of Civil Engineering and Built Environment, Queensland University of Technology, 2 George Street, Brisbane, QLD 4001, Australia. E-mail: paul.xia@qut.edu.au

${ }^{4}$ Lecturer, School of Natural and Built Environment, Queen's University Belfast, David Keir Building, Stranmillis Road, Belfast BT9 5AG, UK. Email: x.meng@qub.ac.uk

5 Associate Professor, School of Built Environment, Curtin University, GPO Box U1987, Perth, WA 6845, Australia. Email: peng.wu@curtin.edu.au
} 
15 the survey data collected from China's megaprojects. The results obtained by partial least

16 squares analysis indicate that both mimetic and normative pressures have significant impacts

17 on OCBEs; and such relationships are partially mediated by organizational support.

18 Nevertheless, this paper did not find the evidence for a significant impact from coercive

19 pressures. These findings provide a new insight into making use of institutional forces to

20 stimulate the emergence of OCBEs, thereby improving the environmental performance in

21 megaprojects.

22 Keywords: Megaprojects; Institutional pressures; Organizational citizenship behaviors for

23 the environment 


\section{Introduction}

25 Megaprojects are temporary endeavors with large investment commitments and vast 26 complexities (Brookes and Locatelli 2015; Wang et al. 2017a). In the construction industry, megaprojects refer to large-scale infrastructure projects that provide public services for the social production, economic development, and people's life, such as long-span bridges, high speed railways, urban metro systems, integrated transport hubs, and energy source bases (Zeng et al. 2015). Over the course of the $21^{\text {st }}$ century, it is notable that the world population

31 is expected to rise by $50 \%$ and reach around 11 billion by 2100 (Roser and Ortiz-Ospina 32 2018). Accompanying this growth will be a sharp increase in demand for megaprojects across 33 a wide range of sectors, such as transportation, mining, water, energy, supply chains, 34 healthcare, and urban regeneration (Flyvbjerg 2014; Hu et al. 2013; Locatelli et al. 2017a; 35 Almohsen and Ruwanpura 2016).

36 Megaprojects are typically commissioned by the government and characterized by "enormous resource consumptions and significant environmental impacts" (Luo et al. 2017; Van Marrewijk et al. 2008; Wang et al. 2017a). The rapid growth of megaprojects yields substantial economic-social benefits, but meanwhile leads to serious environmental problems (Shen et al. 2011; Zeng et al. 2015). Stone (2011) reported in Science that the Three Gorges Dam, the world's largest hydropower project, is an "environmental bane" that will cost USD 26.45 billion over the next decade to mitigate its environmental impacts. Environmental problems arising from construction activities trigger increasing attention globally, pressing megaprojects to advance environmental management in an effective and responsive manner.

The improvement of the environmental performance in megaprojects not only hinges on formal environmental management systems, programs or technologies, but also requires informal and proactive behaviors taken by project practitioners, such as sharing suggestions on on-site pollution prevention, openly questioning of construction activities likely to harm the environment, and collaborating with the project environmental department to promote green initiatives (Fuertes et al. 2013; Wang et al. 2017a; Yusof et al. 2016). These behaviors

51 involve a "sense of citizenship" that is optional or supererogatory and reflects individuals" 
willingness to make extra efforts that contribute to an organization's environmental performance (Boiral 2009). Boiral and Paillé (2012) defined organizational citizenship behaviors for the environment (OCBEs) as "individual and discretionary behaviors that are not explicitly recognized by formal work requirements and that contribute to a more effective environmental management by organizations." As megaprojects apply massive efforts to improve the environmental performance, one of the key challenges is to increase the willingness of project practitioners to support continuous changes and take responsibility against environmental issues on a voluntary and discretionary basis (Hu et al. 2014; Wang et al. 2017b; Zhang et al. 2015a). Otherwise, environmental management system will be inefficient, programs will be poorly implemented, and technologies will be underutilized (He et al. 2015; Raineri and Paillé 2015).

To nurture the willingness of people to adopt responsible environmental behaviors, recent research has linked organizational support with OCBEs (Raineri and Paillé 2015; Paillé and Raineri 2015). Unfortunately, existing OCBEs research has been too fragmented or focused merely on the internal organizational support (e.g., environmental policies and activities), while ignoring the external institutional context. Wang et al. (2017a) examined the extent to which project practitioners' OCBEs are influenced by four types of megaproject environmental responsibility practices, and revealed the internal driving mechanism leading megaproject practitioners to engage in OCBEs; however, how external institutional factors shape the megaproject context and influence project practitioners' OCBEs are largely unexplored. According to DiMaggio and Powell (1983), institutional context is characterized by three main types of pressures (i.e., normative, coercive, and mimetic pressures) and has a far-reaching impact on the way people behave. More specifically, institutional pressures play a crucial role in promoting proactive environmental initiatives and in encouraging "green" behaviors (Liu et al. 2010; Testa et al. 2015). Nevertheless, it remains unclear to which extent OCBEs could be affected by three types of institutional pressures. As highlighted by Boiral et al. (2015), external pressures can indeed reinforce the internal organizational support on environmental management, which, in turn, may foster OCBEs; and there is a "gap between 
the emergent research on OCBEs and the more established literature based on institutional theory and environmental management." For these reasons, this study is guided by the following research question:

How do three types of institutional pressures (i.e., coercive, mimetic, and normative pressures) influence the OCBEs of megaproject practitioners, considering the mediating effect of organizational support?

To summarize, this paper contributes to a new area of megaprojects by exploring the external driving mechanism of OCBEs. The findings will serve as a guideline to harness institutional forces for the improvement of environmental performance and to promote the realization of the broader goal of sustainability in megaprojects. The remainder of this paper is structured as follows. In the next section, the theoretical foundation is provided and research hypotheses are developed. Thereafter, the research method, analytical procedures, and analysis results are illustrated. Finally, the findings and managerial implications on megaproject environmental practices are discussed.

\section{Theoretical Foundation and Hypotheses Development}

\section{Improving Environmental Performance through OCBEs in Megaprojects}

To minimize the adverse impact on environment during the construction stage, megaprojects not only establish rigorous environmental management systems (e.g., ISO 14000), but also introduce a number of green tools (e.g., environmental impact assessment and eco-labeling). However, the effectiveness of environmental management in megaprojects is barely satisfactory (Flyvbjerg et al. 2003). An increasing number of megaproject managers, therefore, begin to realize the diversity and complexity of environmental issues (Molle and Floch 2008), as well as the limitation of formal management systems with fixed and rigid rules (He et al. 2015; Hu et al. 2014; Luo et al. 2017).

As a kind of non-routine and complex projects, megaprojects depend, to a large extent, on innovative contributions from multiple individuals to attain the expected goal (Locatelli et al. 2017a; Maier and Branzei 2014). As a form of innovative and spontaneous pro-environmental 
108 behaviors, OCBEs have been highlighted in megaproject environmental practices. A recent

109 example is Shanghai Disney project (completed by 2016), which adopted a series of incentive

110 measures to encourage the environmentally conscious behaviors of project practitioners, such

111 as early-warning to prevent pollution, suggesting solutions aimed at reducing waste, and

112 collaborating with the project environmental department to implement green technologies

113 (Yang 2016).

\section{Institutional Perspectives on OCBEs}

115 Boiral (2009) indicated that institutional pressures from government agencies or other

116 stakeholders, as conveyed by external motivations and contextual variables, help create a

117 social context that encourages the integration of ecological issues into daily activities.

118 Through the lens of the institutional theory (DiMaggio and Powell 1983), OCBEs may be

119 influenced by three types of pressures.

120 Coercive Pressures

121 Coercive pressures are related to the compulsory pressure exerted by governmental 122 agencies (Zhang et al. 2015b). As megaprojects have been heavily criticized for air, water, 123 noise, and land pollutions, their environmental issues have come under scrutiny by 124 environmental agencies (Zeng et al. 2015). For example, the Three Gorges project has been 125 placed on the "blacklist" of the Ministry of Environmental Protection in China. Drawing on 126 the value-belief-norm theory (Stern et al. 1999), megaproject practitioners often experience 127 changes in "mind-set" in response to strict environmental audits and regulations-the 128 emotional attachment and responsibility to environmental concerns (Wang et al. 2015; Wang 129 et al. 2017b; Yusof et al. 2016). The coercive pressures provide constraints and guidances that 130 promote managers' investments on environmental protection (Testa et al. 2015) and spark 131 individuals' involvements in informal and voluntary behaviors (Lo et al. 2012). Thus, the 132 following hypotheses are presented.

$133 H 1 a$. The level of coercive pressures is positively related to the level of organizational 134 support on environmental protection. 
136 practitioners.

\section{Mimetic Pressures}

138 Mimetic pressures refer to the pressures on an organization to imitate others' successful 139 initiatives (DiMaggio and Powell 1983). As noted by Zhang et al. (2015b), it is reasonable for

140 organizations to benchmark, or even imitate, industrial best-practices to stay competitive in a 141 dynamic and uncertain environment. Due to the complexity and diversity of environmental 142 issues, formal management systems (e.g., ISO 14000) cannot consider all possible initiatives 143 to mitigate environmental impacts (Boiral 2009). In the absence of documented, prescribed, 144 and procedural requirements, there is a real need for a megaproject to learn from others' experiences in dealing with environmental issues. Since megaprojects are characterized by

146 high uncertainties and complexities in nature, their environmental practices face a number of 147 unexpected difficulties and risks. There is no universal environmental practices guide for all 148 megaprojects. Moreover, the effectiveness of environmental practices is largely affected by 149 project characteristics and institutional environments. Therefore, the environmental practices 150 of peer-projects become living examples and important references; and megaproject 151 practitioners are easy to be affected by the practices of those projects with similar institutional 152 environments and project characteristics as their own project (Cao et al. 2014; Locatelli et al. 153 2017b). As megaprojects are criticized for poor environmental performance, project managers 154 need to expand support for keeping abreast of successful practices in peer-projects. As 155 suggested by Boiral et al. (2015), "leading by example" is crucial for individuals to reinforce 156 concerns and commitments towards the environment, thereby motivating their engagements

157 in voluntary environmental behaviors. That is to say, the successful environmental practices 158 of peer-projects will serve as a model to facilitate the emergence of OCBEs among project 159 practitioners. Thus, the following hypotheses are proposed.

$160 H 2 a$. The level of mimetic pressures is positively related to the level of organizational 161 support on environmental protection. 
163 practitioners.

\section{$164 \quad$ Normative Pressures}

165 Normative pressures stem from the professionalization, which is viewed as a form of

166 rules-of-thumb, standards, and norms (Phan and Baird 2015). Professional bodies in the 167 environmental protection field often shape shared values, norms, and standards of what 168 desirable behaviors would be (Cao et al. 2014). These norms and collective expectations are 169 proliferated and developed within the professional field via information exchange activities, 170 including industrial conferences, professional consultations, and vocational educations (He et 171 al. 2016). In the process of megaproject implementations, the normative pressures can be 172 imposed by industry experts, consultant firms, and education institutions accordingly.

173 Compared with coercive pressures, normative pressures have a less mandatory effect on 174 organizational attitudes and behaviors (Cao et al. 2014). Since the environmental impact of 175 megaprojects is tremendous and far-reaching, expert evaluations become a necessary step in 176 project decision-making processes. Additionally, consultant firms and education institutions 177 also exert normative pressures to promote megaprojects to increase investments in 178 environmental issues. Project managers are inclined to show a strong sense of attachment and 179 responsibility to environmental concerns when they have in-depth understandings of the 180 significance and industry expectations regarding environmental issues, thereby enhancing the 181 support on environmental protection. Through systematic training programs, megaproject 182 practitioners accumulate professional knowledge, build a sense of responsibility towards the 183 environment, and demonstrate their willingness to engage in pro-environmental behaviors

184 (Dubey et al. 2015; Paillé and Raineri 2015; Wang et al. 2017b). All of the above discussions 185 lead to the following hypotheses.

$186 H 3 a$. The level of normative pressures is positively related to the level of organizational 187 support on environmental protection.

$188 H 3 b$. The level of normative pressures is positively related to the OCBEs of megaproject 189 practitioners. 
191 Organizational support reflects the degree to which an organization is committed to 192 protecting the environment, and stems from its willingness to recognize and integrate 193 environmental concerns into business strategies (Banerjee et al. 2003). More specifically, the 194 internal organizational support demonstrates the level of megaprojects in defining a clear 195 policy statement, shaping values about the importance of environmental protection, and 196 making efforts to support environmental practices (Paillé et al. 2014). When megaproject 197 practitioners feel encouraged and supported by environmental strategies and policies, they are 198 willing to engage in pro-environmental behaviors so as to help their project to accomplish 199 environmental goals (Hu et al. 2011; Paillé and Raineri 2015).

200 Schaninger and Turnipseed (2005) contended that social exchange has been built on the 201 basis of the norm of reciprocity and occurs when people respond positively to a donor (e.g., 202 an organization) who provides something that is deemed to be valuable. Give and take forms 203 the foundation of exchange relationships. Paillé et al. (2013) empirically validated the 204 positive relationships between organizational support and OCBEs by referring to the social 205 exchange perspective (SEP). Thus, based on the SEP, it can also be inferred that when 206 megaproject managers aim to improve environmental performance and take measures to 207 support their subordinates, the latter would be more likely to "repay" the former by engaging 208 in OCBEs. Considering the role of organizational support in combination with the insights 209 from institutional perspectives, the following hypotheses are developed as follows:

$210 H 4 a$. The level of organizational support is positively related to the OCBEs of megaproject 211 practitioners.

$212 H 4 b$. The level of organizational support mediates the positive relationship between 213 coercive pressures and the OCBEs of megaproject practitioners.

214 H4c. The level of organizational support mediates the positive relationship between 215 mimetic pressures and the OCBEs of megaproject practitioners.

$216 H 4 d$. The level of organizational support mediates the positive relationship between 217 normative pressures and the OCBEs of megaproject practitioners. 


\section{Research Method}

\section{Questionnaire Design}

223 The importance of the questionnaire as an instrument for data collection in behavioral 224 studies is widely recognized (Baruch 1999). Following Elmes et al.'s (2011) suggestions, this 225 study adopts the following steps to ensure the reliability and validity of questionnaires (Fig.2).

226 To begin with, an interview outline, comprising research backgrounds and questions, was 227 designed based on the findings from the literature review of the studies on OCBEs and 228 megaprojects. Six semi-structured interviews were subsequently conducted to refine the 229 research scope and to improve the questionnaire design.

230 To ensure the quality and effectiveness of interviews, a purposive approach was employed 231 to select the targeted interviewees. This approach is suggested by Le et al. (2014a). All the 232 interviewees have at least five years of experience in megaproject management. The main 233 consideration of selecting interviewees is the diversity of professional backgrounds. The 234 interviewees includes both academics and practitioners and involves various project roles, 235 with the aim to increase the heterogeneity of the interview group and thus to expand the depth 236 and width of interview information. OCBEs are considered as a kind of behavioral 237 phenomena. As for phenomenological studies, the recommended number of interviewees is 238 approximately six (Denzin and Lincoln 2008; Marshall et al. 2013). Table 1 shows the 239 backgrounds of six selected interviewees in the current study.

241 The semi-structured interview has been divided into two stages. The first stage is to ask the 242 interviewees to provide some OCBEs cases in their own projects. On this basis, the common 243 forms of OCBEs are identified, which provides the basis for the development of OCBEs 244 measurement items. For example, voice behaviors (making suggestions) were highlighted by 245 interviewees and then a total of two items were used to specifically reflect voice behaviors. 
246 The second stage mainly focuses on "what drives megaproject practitioners to engage in 247 OCBEs and how they will be affected by institutional factors." Then, the sources of three 248 types of institutional pressures are identified. For example, according to the interview, 249 coercive pressures does not merely come from the government, but also relate to the 250 semi-official industry associations in China. Finally, the initial questionnaire was formulated 251 based on the feedbacks of six interviewees.

253 As for institutional pressures, the measurement items of coercive pressures (CPs) were 254 adapted from Cao et al. (2014) and Zhang et al. (2015b), which captured the three 255 authoritative bodies in megaprojects, including regulatory agencies, industry associations, and 256 third-party environmental supervisions. Mimetic pressures (MPs) were measured in view of 257 the perceived effectiveness of environmental protection by peer-projects. Similar items have 258 been employed by He et al. (2016) in construction projects. According to Cao et al. (2014) 259 and Dubey et al. (2015), normative pressures (NPs) reflect the way professional bodies form 260 the norms of environmental protection in megaprojects. A total of three items were adopted to 261 measure the normative influences of consultant firms, industry experts, and academic 262 communities.

263 The construct of organizational support (OS) was operationalized to reflect the project 264 practitioners' feeling of being supported by their project managers. A total of four items were 265 used to reflect OS based on Raineri and Paillé (2015). According to Wang et al. (2017a), the 266 measurement items of OCBEs were developed from five aspects, including helping, 267 sportsmanship, individual initiative, organizational loyalty, and self-development.

268 All selected measures (as shown in Appendix S1.) were assessed using five-point scales 269 from 1 (strongly disagree) to 5 (strongly agree). And these measurement items were 270 translated into Chinese to facilitate the respondent's understanding. This study applied the 271 back-translation technique to ensure the linguistic equivalence of two versions prior to the 272 formal survey (Paillé et al., 2014). 
274 A pre-test involving 23 megaproject professionals (with over 5 years of experience) was 275 performed to evaluate the scope of the questionnaire, to identify the vague expressions of 276 measurement items, and to verify the rationality of related constructs. According to the 277 feedback from pre-test respondents, some measurement items in the initial questionnaire were 278 further revised and then the final version was formed. For example, the CPs item "third-party 279 environmental supervision attaches importance to project environmental protection" was 280 added to the coercive pressures part of the questionnaire. This was because China had issued 281 nationwide regulations mandating the environmental supervision in megaprojects; and hence 282 third-party environmental supervisors play a similar role to that of regulatory agencies in 283 environmental protection.

284 The formal questionnaire survey was conducted between November 2015 and March 2016 285 in China. As China is experiencing the "biggest infrastructure investment boom" in recent 286 years (Ansar et al. 2016), a large number of megaprojects provide the first-hand data for 287 empirical surveys. In the current study, many of the survey respondents come from 288 international megaprojects (e.g., Shanghai Expo and Shanghai Disney) and their experiences 289 are representative even in a global context. Noteworthy, only the megaproject professionals 290 who were directly involved in project environmental practices were considered as the targeted 291 respondents for the formal survey. These professionals should be familiar with environmental 292 laws, regulations, and policies; and have previous experiences in environmental activities 293 (e.g., green design and planning, environmental training and supervision, and eco-friendly 294 construction and materials supply).

295 The scale of the project investment is the most common criterion to distinguish 296 megaprojects from small or medium-sized projects. According to Flyvbjerg (2014), 297 megaprojects refer to large-scale, complex ventures that usually cost more than USD 1 billion. 298 Locatelli et al. (2014) defined megaprojects as "large-scale investment projects typically 299 costing EUR 0.5 billion or more. The investment scale of megaprojects varies by countries. In 300 the current study, the criterion is set as "CNY 1 billion" according to the Chinese context. For 
301 example, Shanghai is one of the megaproject centers in China. In 2016, Shanghai Pudong

302 Megaprojects Management Office (i.e., a government agency) has implemented 109 303 megaprojects, with total investment of CNY 121 billion (Xinhua 2017). The average 304 investment of each megaproject is CNY 1.1 billion. Thus, "CNY 1 billion" is a reasonable 305 criterion for selecting megaprojects. A wide range of megaprojects and potential respondents 306 were identified by a series of approaches, including contacting leading enterprises in 307 megaproject management and consulting, interviewing professionals participating in two 308 megaproject seminars sponsored by the National Natural Science Foundation of China, 309 requesting information from architecture and construction associations, and searching through 310 on-line industry forums and publications. A snowball-sampling approach was employed to 311 expand the sample size (Cao et al. 2014), with the initial respondents being asked to 312 recommend three knowledgeable participants from other megaprojects. A diverse array of 313 megaprojects with different geographic locations and project characteristics was chosen to 314 improve the representativeness of the overall sample, thereby providing a broader vision of 315 industry practices.

316 To enhance the quality of responses, all the respondents were informed of the aim of this 317 study and assured of the confidentiality of their answers for completing the questionnaire. 318 Each of the respondents was given a set of souvenirs (i.e., notepad, gel pen, and bookmark) 319 with the Tongji logo or a cash gift through WeChat. During the formal survey, the 320 respondents were asked to complete the questionnaire according to their most recently 321 experienced megaproject. In addition, the formal survey also included a question "Are you 322 familiar with the project's environmental policies and measures?" to further determine 323 whether the respondent can perceive the project's environmental practices, with the options of 324 "Yes," "No" or "Unsure." The inclusion of an "Unsure" option was used by Norton et al. 325 (2014), with the aim of preventing respondents from making a forced-choice response. 326 Finally, only the respondents who provided a definite answer of "Yes" were retained, while 327 the "No" or "Unsure" answers were considered as invalid responses. 
329 outliers, 198 responses were included in the subsequent analysis. Of the 198 valid responses, $33080(40.40 \%)$ responses were collected via on-site visits, whereas the remaining $73(36.87 \%)$ 331 and $45(22.73 \%)$ responses were collected through a survey system (http://www.sojump.com) 332 and e-mails, respectively. Similarly, the answers from on-site visits, the survey system, and 333 e-mails have no significant difference; the p-values for CPs, MPs, NPs, OS, and OCBEs are $3340.922,0.282,0.663,0.482$, and 0.415 , respectively.

335 Demographic characteristics of the surveyed projects and respondents are shown in Table 2. 336 The surveyed respondents are well-informed senior and professional individuals from all 337 across China. Among the 198 valid responses, 72 were from owners, 61 from contractors, 39 338 from consultants, and 26 from designers and suppliers. An analysis of variance (ANOVA) 339 was performed to make a comparison of the answers from owners, contractors, consultants, as 340 well as designers and suppliers; the p-values for CPs, MPs, NPs, OS, and OCBEs are 0.485, $3410.644,0.281,0.650$, and 0.936 , respectively. This result suggests that the answers from the 342 four groups of responses have no significant difference ( $p$-values are all above 0.05).

\section{Tools for Data Analysis}

345 Both exploratory factor analysis (EFA) and confirmatory factor analysis (CFA) were used 346 to examine the reliability and validity of the measurement model. EFA along with the 347 principal component analysis (PCA) was performed to identify the factor structure and to 348 refine the measurement items, whereas CFA was conducted to further verify the results of 349 EFA (Cao et al. 2017).

350 Partial least square (PLS) analysis was applied to test the research hypotheses. The main 351 reason for using PLS is that it has minimal requirements on the sample size and residual 352 distribution to achieve the expected statistical power and robustness (Hair et al. 2013). More 353 specifically, it is most applicable to the early-stage theory development and testing without 354 requiring a large sample size (normally more than 200), which fits well with the exploratory 355 nature of this study. PLS is also distribution-free and thus appropriate for the data from the 


\section{Data Analysis and Results}

\section{$360 \quad$ Factor Analysis}

361 EFA was first conducted for the 10 items of institutional pressures. The 362 Kaiser-Meyer-Olkin (KMO) value is $0.812>0.6$, suggesting satisfactory sample adequacy 363 (Field 2009). The Bartlett's Test of Sphericity (BTS) produces an approximation of $\chi^{2}=$ $364640.859(d f=45, p=0.000<0.001)$, which indicates that the variable correlation is 365 sufficiently strong for PCA (George 2003). Hair et al. (2010) noted that the loading of each 366 measurement item on its corresponding construct should be greater than 0.5. Thus, MP4 367 (0.365) was deleted from the list of measurement items.

368 A follow-up PCA was conducted for the 9 remaining items. The KMO value is 0.795 , 369 thereby exceeding the 0.6 threshold; BTS reaches statistical significance $\left(\chi^{2}=588.820, d f\right.$ $370=36, p=0.000<0.001)$. As consequence, three different factors were extracted to reflect the 371 CPs, MPs, and NPs constructs. Table 3 shows that the rotated loadings of the manifest items 372 on their intended constructs all exceed 0.5 and are greater than the loadings on other 373 constructs. These results validate the appropriateness of using the 9 listed institutional 374 pressures items to reflect CPs, MPs, and NPs constructs.

$$
<\text { Insert Table 3> }
$$

376 CFA was subsequently performed to further verify the three-factor structure of institutional 377 pressures. Table 4 indicates that the factor structure of institutional pressures has acceptable 378 fit level as judged by goodness-of-fit indicators (Fang et al. 2015).

\section{Evaluation of the Measurement Model}

381 The validity of all the measurements was further assessed from the following three aspects. 382 Firstly, internal consistency was assessed in terms of the composite reliability (CR) and 
383 Cronbach's $\alpha$. Table 5 shows that the values of CR and Cronbach's $\alpha$ are all greater than 0.7, 384 indicating a satisfactory reliability of the (Hair et al. 2011). Secondly, convergent validity is 385 assessed by the values of the average variance extracted (AVE). The AVE values are all 386 greater than 0.5 (Table 5), suggesting that these constructs have a satisfactory convergent 387 validity (Hair et al. 2011). In addition, the convergent validity is also evaluated by the factor 388 loadings of each measurement item. As shown in Table 6, the factor loadings of each item on 389 its respective construct are all greater than the 0.7 threshold; and no cross-loading problem 390 exists (Hair et al. 2011). Thirdly, Table 5 also shows that the square roots of AVE (diagonal 391 values in the correlation matrix) are all above the absolute value of inter-construct 392 correlations (off-diagonal values), indicating a satisfactory discriminant validity of the 393 constructs (Hair et al. 2011).

396 As the quantitative data were collected from a single source (i.e., questionnaires), there is a 397 possibility that common-method bias may arise (Podsakoff et al. 2003). Harman's 398 single-factor test was used to further analyze the possibility of common method bias. The test results show that there is no single leading factor; and the most prominent one merely 400 accounts for $21.886 \%$ of the total variances in measurements, indicating that the common 401 method bias is limited in this study.

\section{$402 \quad$ Hypothesis Testing and Results Analysis}

403 A bootstrapping approach with 5,000 resamples was employed for the hypothesis testing. 404 The results of the bootstrap-based analysis are shown in Fig. 3 and Table 7. The $R^{2}$ value of 405 the dependent variable (i.e., OCBEs) is 0.446 , indicating that most of the variances in the 406 construct can be explained by the research model. The MPs-OS link $(\beta=0.340, p<0.001)$ 407 and NPs-OS link $(\beta=0.296, p<0.001)$ are all significant, thus both Hypotheses $2 \mathrm{a}$ and $3 \mathrm{a}$ 408 are supported. Whereas, the CPs-OS link is non-significant $(\beta=0.093, p>0.05)$, therefore 409 Hypothesis 1a is not supported. In addition, the influence of OS on OCBEs is significant $(\beta=$ $4100.239, p<0.001)$, thus Hypothesis $4 \mathrm{a}$ is supported. 
412 Regarding the relationships between institutional pressures and OCBEs, only the influence

413 of CPs is non-significant when the effect of OS is included $(\beta=0.056, p>0.05)$, thus

414 Hypothesis $1 \mathrm{~b}$ is not supported. Meanwhile, the MPs-OCBEs link $(\beta=0.297, p<0.001)$ and

415 NPs-OCBEs link $(\beta=0.264, p<0.001)$ are all significant, hence both Hypotheses $2 \mathrm{~b}$ and $3 \mathrm{~b}$

416 are supported. Considering the significant links between MPs and OS and between OS and

417 OCBEs, it can be inferred that the influence of MPs on OCBEs is partially mediated by OS.

418 Similar conclusion is also reached for NPs, therefore Hypotheses $4 \mathrm{c}$ and $4 \mathrm{~d}$ are supported.

419 However, in view of the non-significant links between CPs and OS and between CPs and 420 OCBEs, Hypothesis $4 \mathrm{~b}$ is not supported.

$<$ Insert Fig.3 $>$

422 To further investigate the effects of CPs, MPs, and NPs on OCBEs, an alternative model 423 without the mediator was tested (Fig. 4). Although the mediating effect of OS is excluded, the 424 direct impact of CPs on OCBEs is still non-significant. Thus, Hypothesis $1 b$ is not supported.

\section{Discussions, Implications and Future Research}

\section{Discussions}

The main objective of the current study is to obtain a better understanding of the institutional-psychological mechanism underlying innovative and spontaneous behaviors directed at environmental improvement in megaprojects. Overall, the results provide the evidence that the internal organizational support plays an important role in the connection between external institutional pressures and OCBEs; and institutional pressures exert a significant impact on the emergence of OBCEs in general. It is notable, however, that

434 organizational support is not simply to introduce the environmental management system 435 (EMS) or green technologies, and different types of institutional pressures affect OCBEs differently.

437 Understanding the drivers of OCBEs by focusing on the internal organizational support 438 only sees the one side of the coin. Given rising concerns regarding the environmental 
sustainability, megaprojects are challenged with growing external pressures by a wide range

440 of stakeholders (e.g., regulatory agencies, industry associations, and benchmark projects) to

441 become environmentally friendly in their implementation process (Wang et al. 2017b; Zeng et 442 al.2015). And the institutional conditions in which project implements (Hayes and 443 Karamichas 2011) are important enablers that shape the project context and affect project 444 practitioners' environmental behaviors (Yusof et al. 2016). Boiral et al. (2015) posited that 445 institutional pressures in the form of environmental regulations or stakeholders' expectations 446 have positive influences on the emergence of OCBEs. Interestingly, the findings confirm the 447 crucial role of mimetic and normative pressures in promoting OCBEs; however, coercive 448 pressures only have a non-significant or marginally significant effect on OCBEs.

\section{$449 \quad$ Managerial Implications}

450 The findings of this study provide four main implications for megaproject managers 451 seeking to improve the effectiveness of environmental practices and to achieve the goal of 452 project greening.

453 Firstly, the adoption of EMS is increasingly advocated as an effective approach for 454 supporting the "greening process" in project-based organizations (Chong et al. 2009; Zhang et 455 al. 2015a). However, if the involvement of project practitioners is insufficient, EMS tends to 456 be disconnected from daily construction activities and to be deployed symbolically rather than 457 substantially (Boiral et al. 2016; Robichaud and Anantatmula 2010; Wang et al. 2017a; Yusof 458 et al. 2016). For example, an interviewee with more than 15 years of megaproject 459 management experience noted that "EMS became an expensive gimmick to please the 460 government in some megaprojects; a lot of organizational support measures towards 461 environmental protection only remained on the document." This study provides a novel 462 perspective that may explain why there is a poor environmental performance for some 463 megaprojects that seem to have made great efforts to implement EMS. For these megaprojects, 464 the implementation of EMS often becomes an "effective" way of increasing the external 465 social reputations, rather than improving the internal environmental management 466 practices-also known as "green-washing" (De Roeck and Delobbe 2012). When project 
practitioners are confused about the real intentions of their megaproject to adopt EMS, they

468 are less willing to engage in OCBEs. This study provides the evidence that the most effective 469 way to foster project practitioners' OCBEs is to establish the priority of environmental goals 470 in project contracts. Furthermore, the establishment of environmental orientation also needs to 471 combine with concrete supportive actions (e.g., training and communication opportunities), 472 thereby sending a clear signal to all the practitioners about the values and priorities of their 473 project. Moreover, managers can nurture and support the willingness of megaproject 474 practitioners to engage in OCBEs, especially through enhancing psychological empowerment 475 (Tuuli et al. 2013) and relationship quality (Zheng et al. 2018).

476 Secondly, megaprojects are "large unique projects" where public sectors often act as 477 clients/owners, and hence are very likely to be in a regulatory "gap" (Hosseini et al. 2017; 478 Locatelli et al. 2017a). In China, megaprojects are usually launched by the central 479 government and/or local government, and even the government's supervisory departments are 480 also involved. For example, the construction committee of Three Gorges Dam includes the 481 vice prime minister of the state council of China, the mayor of Chongqing City, the 482 vice-minister of the Ministry of Environmental Protection, and etc. The government plays a 483 double role as both "athlete and referee." This pattern (i.e., completely 484 government-dominated) contributes greatly to the efficiency of megaproject implementation 485 process; however, it also brings hidden dangers (e.g., corruptions) that may weaken the 486 mechanism of regulations (Le et al. 2014b). In the context of strong governments and weak 487 regulations (Zeng et al. 2015), coercive pressures are inefficient to increase megaproject 488 practitioners' willingness to make efforts for environmental practices. In this case, 489 independent third-party environmental supervisors and auditors can fill the regulatory "gap," 490 and more importantly provide guidances and encouragements for megaproject practitioners to 491 adopt environmentally responsible behaviors.

492 Thirdly, with the exception of coercive pressures, both mimetic and normative pressures 493 have significant impacts on OCBEs. It is noteworthy that mimetic pressures are the most 494 influential external driver of OCBEs, which further confirms the key role of "leading by 
example" in promoting OCBEs (Boiral et al. 2015). The benchmark practice of peer-projects

496 tends to speak much louder than words (e.g., project documents and industry standards).

497 Therefore, in order to increase the willingness of megaproject practitioners to support

498 environmental practices on a voluntary and discretionary basis, one effective approach is to

499 organize regular communication activities with peer-projects and thus to facilitate knowledge

500 exchanges and mutual learning. In particular, megaproject practitioners need regularly get

501 access to the best environmental practices within benchmark projects and develop a learning

502 routine for the external knowledge exploration (Manley and Chen 2017). For example,

503 Shanghai Housing and Urban-Rural Construction Committee launched a competition of 504 "pioneer megaprojects" in 2016 to mobilize the resources of people in spontaneous 505 cooperation as well as innovative and volunteering behaviors.

506 Finally, another external determinant of OCBEs is normative pressures, whose effect is 507 evidently weaker than mimetic pressures. During the megaproject implementation process, 508 industry professional bodies play a crucial role in disseminating information on innovative 509 environmental measures and in advocating cutting-edge green technologies. However, an 510 interviewee in this study has noted that "the actual level of involvement of professional 511 communities is not high in China's megaprojects," which partly explains why the impact of 512 normative pressures on OCBEs is moderate. To address this issue, one possible way is to 513 introduce external facilitators or behavioral consultants from industry associations (e.g., 514 LEED accredited professionals) to guide the improvement of megaproject environmental 515 practices and to promote the sharing of environmental knowledge (Love et al. 2015).

\section{$516 \quad$ Limitations and Future Research Directions}

517 This study extends the recent research on environmental behaviors in the construction 518 industry (Wang et al. 2017a; Wu et al. 2017; Yusof et al. 2016) by providing further insights 519 into the external mechanism underlying project practitioners' willingness to sustain the 520 environmental efforts of megaprojects. Notwithstanding its contributions, the current study 521 has several limitations that call for future research. Firstly, this study is based on a specific 522 institutional context (i.e., China), which might affect the generalizability of the empirical 
523 findings to other institutional contexts. The next stage of OCBEs research can compare the

524 impacts of institutional pressures between different countries (e.g., US and China). Secondly, 525 although a series of methodological measures were employed to minimize the effects of 526 common method bias and social desirability, it is essential to recognize that this study was 527 cross-sectional and all the data was collected from self-report questionnaires. A future study 528 may be conducted by using the longitudinal data to validate the reliability of observed 529 correlations and by introducing objective measures (e.g., third-party evaluations) to assess the 530 behavioral performance. Thirdly, this study focused on the individual-level OCBEs, hence 531 future research may explore the drivers that enable the manifestation of OCBEs at the 532 project-level.

\section{Conclusions}

535 Under the enormous pressures of environmental protection, the construction process of 536 megaprojects shows a shift from the emphasis on "iron triangles" (i.e., cost, quality, and time) 537 to sustainability. Most megaproject sustainable research tends to neglect the key role of 538 OCBEs in improving the environmental performance and little is known regarding the 539 institutional-psychological mechanism leading megaproject practitioners to engage in OCBEs. 540 To address this research gap, this paper investigates the external determinants of OCBEs in 541 megaprojects at the individual-level. The findings provide new insights into the use of 542 institutional forces to facilitate the improvement of the environmental performance in 543 megaprojects, especially for some developing countries (e.g., China, India, and Brazil) that 544 are undergoing a massive infrastructure construction. All these rapidly emerging major 545 economies are in a similar institutional environment and face common problems, such as 546 unpredictable or inconsistent government regulations, insufficient or limited industry 547 information, and lack of status and respect for markets (Gupta et al. 2014).

548 Although extant research contends that institutional pressures are essential determinants of 549 OCBEs (Boiral et al. 2015; Lülfs and Hahn 2013), this exploratory study indicates that the 550 nature and implications of these pressures are not monolithic in megaprojects. Mimetic 
551 pressures are the most significant external determinant of OCBEs, followed by normative 552 pressures. Interestingly, coercive pressures from government bodies and agencies exert a 553 non-significant impact on OCBEs. Future studies on the external determinants of OCBEs 554 should not use one latent variable to represent different pressures from various institutional 555 constituents. This approach may mix the different impacts of institutional pressures and 556 weaken the explanatory power of institutional perspectives.

557 Additionally, this paper also shows that mimetic and normative pressures have both direct 558 and indirect effects on OCBEs, leading to the conclusion that these relationships are partially 559 mediated by organizational support. The findings suggest the usefulness of combining the 560 social exchange process (e.g., reciprocity between organizations and their members) with the 561 institutionalization process (e.g., search for social legitimacy) to enhance megaproject 562 practitioners' motivation to engage in OCBEs.

\section{Acknowledgments}

565 This paper is based on an earlier paper presented at the EPOC-MW 2017 Conference, 566 Fallen Leaf Lake, CA USA. This work was supported by the National Natural Science 567 Foundation of China (Project No.: 71571137, 71471136, and 71390523). The authors 568 appreciate the editors and reviewers for their valuable suggestions.

\section{Supplemental Data}

571 Appendix S1 is available online in the ASCE Library (www.ascelibrary.org).

\section{References}

574 Aibinu, A. A., \& Al-Lawati, A. M. (2010). Using PLS-SEM technique to model construction 575 organizations' willingness to participate in e-bidding. Automation in Construction, 19 (6), 714-724.

576 Almohsen, A. S., \& Ruwanpura, J. Y. (2016). Establishing Success Measurements of Joint Ventures in 577 Mega Projects. Journal of Management in Engineering, 32(6), 04016018. 
Ansar, A., Flyvbjerg, B., Budzier, A., \& Lunn, D. (2016). Does infrastructure investment lead to economic growth or economic fragility? Evidence from China. Oxford Review of Economic Policy, 32(3), 360-390.

Banerjee, S. B., Iyer, E. S., \& Kashyap, R. K., 2003. Corporate environmentalism: Antecedents and influence of industry type. Journal of Marketing, 67 (2), 106-122.

Baruch, Y. (1999). Response rate in academic studies-A comparative analysis. Human relations, 52(4), 421-438.

Boiral, O. (2009). Greening the corporation through organizational citizenship behaviors. Journal of Business Ethics, 87 (2), 221-236.

Boiral, O., \& Paillé, P. (2012). Organizational citizenship behaviour for the environment: Measurement and validation. Journal of Business Ethics, 109(4), 431-445.

Boiral, O., Talbot, D., \& Paillé, P. (2015). Leading by example: A model of organizational citizenship behavior for the environment. Business Strategy and the Environment, 24 (6), 532-550.

Boiral, O., Raineri, N., \& Talbot, D. (2016). Managers' Citizenship Behaviors for the Environment: A Developmental Perspective. Journal of Business Ethics, 1-15.

Brookes, N. J., \& Locatelli, G. (2015). Power plants as megaprojects: Using empirics to shape policy, planning, and construction management. Utilities Policy, 36, 57-66.

Cao, D., Li, H., \& Wang, G. (2014). Impacts of isomorphic pressures on BIM adoption in construction projects. Journal of Construction Engineering and Management, 140(12), 04014056.

Cao, D., Li, H., Wang, G., \& Huang, T. (2017). Identifying and contextualising the motivations for BIM implementation in construction projects: An empirical study in China. International Journal of Project Management, 35 (4), 658-669.

Chong, W. K., Kumar, S., Haas, C. T., Beheiry, S. M., Coplen, L., \& Oey, M. (2009). Understanding and interpreting baseline perceptions of sustainability in construction among civil engineers in the United States. Journal of Management in Engineering, 25(3), 143-154.

De Roeck, K., \& Delobbe, N. (2012). Do environmental CSR initiatives serve organizations' legitimacy in the oil industry? Exploring employees' reactions through organizational identification theory. Journal of Business Ethics, 110(4), 397-412.

Denzin, N. K., \& Lincoln, Y. S. (2008). Strategies of qualitative inquiry (Vol. 2). Sage, Thousand Oaks.

DiMaggio, P.J., Powell, W.W. (1983). The Iron Cage Revisited: Institutional Isomorphism and Collective Rationality in Organizational Fields. American Sociological Review, 48 (2), 147-160.

Dubey, R., Gunasekaran, A., \& Ali, S. S. (2015). Exploring the relationship between leadership, operational practices, institutional pressures and environmental performance: A framework for green supply chain. International Journal of Production Economics, 160, 120-132.

Elmes, D. G., Kantowitz, B. H., \& Roediger III, H. L. (2011). Research methods in psychology. Nelson Education, Toronto.

Fang, D., Wu, C., \& Wu, H. (2015). Impact of the supervisor on worker safety behavior in construction projects. Journal of Management in Engineering, 31(6), 04015001.

Field, A. (2009). Discovering statistics using SPSS. Sage, London.

Flyvbjerg, B., Bruzelius, N., \& Rothengatter, W. (2003). Megaprojects and risk: An anatomy of ambition. Cambridge University Press, Cambridge. 
Flyvbjerg, B. (2014). What you should know about megaprojects and why: an overview. Project

621 Management Journal, 45 (2), 6-19.

Fuertes, A., Casals, M., Gangolells, M., Forcada, N., Macarulla, M., \& Roca, X. (2013). An environmental impact causal model for improving the environmental performance of construction processes. Journal of Cleaner Production, 52, 425-437.

George, D. (2003). SPSS for windows step by step: A simple study guide and reference, 17.0 update, 10/e. Pearson Education India, Delhi.

627 Gupta, V. K., Guo, C., Canever, M., Yim, H. R., Sraw, G. K., \& Liu, M. (2014). Institutional environment for entrepreneurship in rapidly emerging major economies: the case of Brazil, China, India, and Korea. International Entrepreneurship and Management Journal, 10(2), 367-384. Hair, J. F., Anderson, R. E., Babin, B. J., \& Black, W. C. (2010). Multivariate data analysis: A global perspective (Vol. 7). Pearson Prentice Hall, Upper Saddle River.

632 Hair, J. F., Ringle, C. M., \& Sarstedt, M. (2011). PLS-SEM: Indeed a silver bullet. Journal of Marketing Theory and Practice, 19(2), 139-152.

634 Hair Jr, J. F., Hult, G. T. M., Ringle, C., \& Sarstedt, M. (2013). A primer on partial least squares structural equation modeling (PLS-SEM). Sage, London.

636 Hayes, G., \& Karamichas, J. (Eds.). (2011). Olympic Games, mega-events and civil societies: Globalization, environment, resistance. Springer.

638 He, Q. H., Yang, D. L., Li, Y. K., \& Luo, L. (2015). Research on Multidimensional Connotations of 639 Megaproject Construction Organization Citizenship Behavior. Frontiers of Engineering Management, $640 \quad 2(2), 148-153$.

641 He, Q., Dong, S., Rose, T., Li, H., Yin, Q., \& Cao, D. (2016). Systematic impact of institutional 642 pressures on safety climate in the construction industry. Accident Analysis \& Prevention, 93, 230-239.

643 Hosseini, M. R., Banihashemi, S., Martek, I., Golizadeh, H., \& Ghodoosi, F. (2017). Sustainable 644 Delivery of Megaprojects in Iran: Integrated Model of Contextual Factors. Journal of Management in 645 Engineering, 34(2), 05017011.

646 Hu, Y., Chan, A. P., Le, Y., Jiang, W. P., Xie, L. L., \& Hon, C. H. (2011). Improving megasite 647 management performance through incentives: Lessons learned from the Shanghai Expo construction. 648 Journal of Management in Engineering, 28(3), 330-337.

649 Hu, Y., Chan, A. P., Le, Y., \& Jin, R. Z. (2013). From construction megaproject management to 650 complex project management: Bibliographic analysis. Journal of Management in Engineering, 31(4), 65104014052.

652 Hu, Y., Chan, A. P., \& Le, Y. (2014). Understanding the determinants of program organization for 653 construction megaproject success: Case study of the shanghai expo construction. Journal of 654 Management in Engineering, 31(5), 05014019.

655 Le, Y., Shan, M., Chan, A. P., \& Hu, Y. (2014a). Investigating the causal relationships between causes 656 of and vulnerabilities to corruption in the Chinese public construction sector. Journal of Construction 657 Engineering and Management, 140(9), 05014007.

658 Le, Y., Shan, M., Chan, A. P., \& Hu, Y. (2014b). Overview of corruption research in construction. 659 Journal of Management in Engineering, 30(4), 02514001. 
661 mechanism of proactive corporate environmental management in China. Journal of Environmental Management, 91 (8), 1707-1717.

663 Lo, S. H., Peters, G. J. Y., \& Kok, G. (2012). A review of determinants of and interventions for proenvironmental behaviors in organizations. Journal of Applied Social Psychology, 42(12), 2933-2967. Locatelli, G., Littau, P., Brookes, N. J., \& Mancini, M. (2014). Project characteristics enabling the success of megaprojects: An empirical investigation in the energy sector. Procedia-Social and Behavioral Sciences, 119, 625-634. Locatelli, G., Mariani, G., Sainati, T., \& Greco, M. (2017a). Corruption in public projects and megaprojects: There is an elephant in the room!. International Journal of Project Management, 35(3), $252-268$.

672 Locatelli, G., Invernizzi, D. C., \& Brookes, N. J. (2017b). Project characteristics and performance in 673 Europe: An empirical analysis for large transport infrastructure projects. Transportation Research Part 674 A: Policy and Practice, 98, 108-122.

675 Love, P. E., Ackermann, F., Teo, P., \& Morrison, J. (2015). From individual to collective learning: A 676 conceptual learning framework for enacting rework prevention. Journal of Construction Engineering and Management, 141(11), 05015009.

678 Lülfs, R., \& Hahn, R. (2013). Corporate greening beyond formal programs, initiatives, and systems: a conceptual model for voluntary pro-environmental behavior of employees. European Management 680 Review, 10(2), 83-98.

681 Luo, L., He, Q., Xie, J., Yang, D., \& Wu, G. (2017). Investigating the Relationship between Project 682 Complexity and Success in Complex Construction Projects. Journal of Management in Engineering, 683 33(2), 04016036.

684 Maier, E. R., \& Branzei, O. (2014). "On time and on budget”: Harnessing creativity in large scale projects. International Journal of Project Management, 32 (7), 1123-1133.

686 Manley, K., \& Chen, L. (2017). Collaborative Learning to Improve the Governance and Performance 687 of Infrastructure Projects in the Construction Sector. Journal of Management in Engineering, 33(5), 68804017030.

689 Marshall, B., Cardon, P., Poddar, A., \& Fontenot, R. (2013). Does sample size matter in qualitative 690 research?: A review of qualitative interviews in IS research. Journal of Computer Information Systems, 691 54(1), 11-22.

692 Molle, F., \& Floch, P. (2008). Megaprojects and social and environmental changes: The case of the 693 Thai “water grid". AMBIO: A Journal of the Human Environment, 37 (3), 199-204.

694 Norton, T. A., Zacher, H., \& Ashkanasy, N. M. (2014). Organisational sustainability policies and 695 employee green behaviour: The mediating role of work climate perceptions. Journal of Environmental 696 Psychology, 38, 49-54.

697 Paillé, P., Boiral, O., \& Chen, Y. (2013). Linking environmental management practices and 698 organizational citizenship behaviour for the environment: a social exchange perspective. International 699 Journal of Human Resource Management, 24 (18), 3552-3575.

700 Paillé, P., Chen, Y., Boiral, O., \& Jin, J. (2014). The impact of human resource management on 701 environmental performance: An employee-level study. Journal of Business Ethics, 121(3), 451-466. 
Paillé, P., \& Raineri, N. (2015). Linking perceived corporate environmental policies and employees eco-initiatives: The influence of perceived organizational support and psychological contract breach. Journal of Business Research, 68(11), 2404-2411.

Phan, T. N., \& Baird, K. (2015). The comprehensiveness of environmental management systems: The influence of institutional pressures and the impact on environmental performance. Journal of Environmental Management, 160, 45-56.

Podsakoff, P. M., MacKenzie, S. B., Lee, J. Y., \& Podsakoff, N. P. (2003). Common method biases in behavioral research: A critical review of the literature and recommended remedies. Journal of Applied Psychology, 88(5), 879-903.

Raineri, N., \& Paillé, P. (2015). Linking corporate policy and supervisory support with environmental citizenship behaviors: the role of employee environmental beliefs and commitment. Journal of Business Ethics, 1-20.

Robichaud, L. B., \& Anantatmula, V. S. (2010). Greening project management practices for sustainable construction. Journal of Management in Engineering, 27(1), 48-57.

Roser M., \& Ortiz-Ospina E. (2018). World Population Growth. (https://ourworldindata.org/world-population-growth).

Schaninger, W. S., \& Turnipssed, D. L. (2005). The workplace social exchange network: Its effect on organizational citizenship behavior, contextual performance, job. Handbook of Organizational Citizenship Behavior: A Review of 'Good Solder' Activity in Organizations. Nova Science Publishers, New York.

Shen, L., Wu, Y., \& Zhang, X. (2011). Key assessment indicators for the sustainability of infrastructure projects. Journal of Construction Engineering and Management, 137(6), 441-451.

Stern, P. C., Dietz, T., Abel, T. D., Guagnano, G. A., \& Kalof, L. (1999). A value-belief-norm theory of support for social movements: The case of environmentalism. Human Ecology Review, 6(2), 81-97.

Stone, R. (2011). Hydropower. The legacy of the Three Gorges Dam. Science, 333 (6044), 817.

Testa, F., Boiral, O., \& Iraldo, F. (2015). Internalization of Environmental Practices and Institutional Complexity: Can Stakeholders Pressures Encourage Greenwashing?. Journal of Business Ethics, 1-21.

Tuuli, M. M., Rowlinson, S., Fellows, R., \& Liu, A. M. (2013). Individual-level antecedents of psychological empowerment. Journal of Management in Engineering, 31(2), 04014036.

Van Marrewijk, A., Clegg, S. R., Pitsis, T. S., \& Veenswijk, M (2008). Managing public-private megaprojects: Paradoxes, complexity, and project design. International Journal of Project Management, 26(6), 591-600.

Wang, J., Li, Z., \& Tam, V. W. (2015). Identifying best design strategies for construction waste minimization. Journal of Cleaner Production, 92, 237-247.

Wang, G., He, Q, Meng, X., Locatelli, G., Yu, T., Yan, X. (2017a). Exploring the impact of megaproject environmental responsibility on organizational citizenship behaviors for the environment: A social identity perspective. International Journal of Project Management, 35(7), 1402-1414.

Wang, G., He, Q, Locatelli, G., Yan, X., Yu, T. (2017b). The effects of institutional pressures on organizational citizenship behaviors for the environment in managing megaprojects, Working Paper Series, Proceedings of the EPOC-MW Conference, Engineering Project Organization Society, Fallen Leaf Lake, CA USA, June 5-7, 2017. 
Wu, Z., Ann, T. W., \& Shen, L. (2017). Investigating the determinants of contractor's construction and

744 demolition waste management behavior in Mainland China. Waste Management, 60, 290-300.

745 Xinhua (Shanghai), 2017. The development of 106 Megaprojects in Pudong, Shanghai in 2016.

746 (http://www.sh.xinhuanet.com/2017-01/04/c_135954470.htm). (In Chinese)

747 Yang, J. M., 2016. Environmental Management in Mega Construction Projects. East China University

748 of Science and Technology Press, Shanghai. (In Chinese)

749 Yusof, N. A., Abidin, N. Z., Zailani, S. H. M., Govindan, K., \& Iranmanesh, M. (2016). Linking the

750 environmental practice of construction firms and the environmental behaviour of practitioners in 751 construction projects. Journal of Cleaner Production, 121, 64-71.

752 Zeng, S. X., Ma, H. Y., Lin, H., Zeng, R. C., \& Tam, V. W. (2015). Social responsibility of major 753 infrastructure projects in China. International Journal of Project Management, 33(3), 537-548.

754 Zhang, X., Wu, Y., \& Shen, L. (2015a). Embedding "green" in project-based organizations: the way 755 ahead in the construction industry?. Journal of Cleaner Production, 107, 420-427.

756 Zhang, B., Wang, Z., \& Lai, K. H. (2015b). Mediating effect of managers' environmental concern:

757 Bridge between external pressures and firms' practices of energy conservation in China. Journal of

758 Environmental Psychology, 43, 203-215.

759 Zheng, X., Lu, Y., Le, Y., Li, Y., \& Fang, J. (2018). Formation of interorganizational relational

760 behavior in megaprojects: Perspective of the extended theory of planned behavior. Journal of

$761 \quad$ Management in Engineering, 34(1), 04017052. 
Fig.1. Research framework

779 Fig.2. Flowchart of questionnaire development

780 Fig. 3. Results of PLS analysis for the original research model

781 Fig. 4. Results of PLS analysis for the alternative research model

782

783

784

785

786

787

788

789

790

791

792

793

794

795

796

797

798

799

800

801

802

803

804 


\begin{tabular}{ccccc}
\hline No. & Employer & Position & $\begin{array}{c}\text { Years of megaproject } \\
\text { experience }\end{array}$ & Involved megaprojects \\
\hline 1 & Owner & Project manager & 8 & $\begin{array}{c}\text { Shanghai West Bank Media Port } \\
\text { Project manager }\end{array}$ \\
2 & Consultant & 15 & Suzhou-Nantong Bridge and Shanghai Disney \\
3 & Government & Project manager & 5 & Shanghai Expo \\
4 & Contractor & Project manager & 6 & Tianjin Heat Supply and Grid Connection \\
5 & Academic & Professor & 16 & Shanghai Expo and Shanghai Disney \\
6 & Academic & Professor & 23 & Shanghai Expo and Shanghai Disney \\
\hline
\end{tabular}

806

807

808

809

810

811

812

813

814

815

816

817

818

819

820 
Table 2. Demographic Information of Respondents.

\begin{tabular}{|c|c|c|c|}
\hline Variable & Category & Number of respondents & Percentage \\
\hline \multirow{5}{*}{ Project role } & Owner/Government & 72 & 36.36 \\
\hline & Contractor & 61 & 30.81 \\
\hline & Consultant & 39 & 19.70 \\
\hline & Designer & 14 & 7.07 \\
\hline & Supplier & 12 & 6.06 \\
\hline \multirow{6}{*}{ Project type } & Large-scale exhibition facility/ industry zone & 63 & 31.82 \\
\hline & Urban metro system & 41 & 20.71 \\
\hline & Integrated transport hubs & 37 & 18.69 \\
\hline & Energy source bases & 25 & 12.62 \\
\hline & High speed railways & 18 & 9.09 \\
\hline & Long-span bridge & 14 & 7.07 \\
\hline \multirow{5}{*}{ Location $^{\mathrm{a}}$} & East China & 95 & 47.98 \\
\hline & South China & 36 & 18.18 \\
\hline & North China & 32 & 16.16 \\
\hline & West China & 21 & 10.61 \\
\hline & Central China & 14 & 7.07 \\
\hline \multirow{4}{*}{ Position } & Project manager & 58 & 29.29 \\
\hline & Department manager & 31 & 15.66 \\
\hline & Professional executive & 45 & 22.73 \\
\hline & Project engineer & 64 & 32.32 \\
\hline \multirow{5}{*}{$\begin{array}{l}\text { Years of } \\
\text { experience }\end{array}$} & $\leqslant 5$ year & 55 & 27.78 \\
\hline & 6-10 year & 61 & 30.81 \\
\hline & 11-15year & 48 & 24.24 \\
\hline & $16-20$ year & 19 & 9.59 \\
\hline & $>20$ year & 15 & 7.58 \\
\hline
\end{tabular}

823 Note: Location ${ }^{a}$ refers to the project site. 
Table 3. Component List of Institutional Pressures.

\begin{tabular}{cccc}
\hline & \multicolumn{3}{c}{ Factor loadings } \\
\cline { 2 - 4 } Measurement items & Factor 1 & Factor 2 & Factor 3 \\
\hline NPs2 & $\mathbf{. 8 5 1}$ & .199 & .082 \\
NPs1 &. $\mathbf{8 2 9}$ & .094 & .178 \\
NPs3 &. $\mathbf{7 5 5}$ & .045 & .303 \\
CPs2 & .126 &. $\mathbf{8 2 9}$ & -.007 \\
CPs1 & .170 & $\mathbf{. 8 1 0}$ & .120 \\
CPs3 & .008 &. $\mathbf{7 8 8}$ & .268 \\
MPs1 & .067 & .181 & $\mathbf{. 8 5 6}$ \\
MPs2 & .204 & .141 &. $\mathbf{7 7 8}$ \\
MPs3 & .424 & .031 & $\mathbf{. 7 2 6}$ \\
Variance cumulatively explained (\%) & 24.432 & 47.448 & 70.365 \\
\hline Variance explained (\%) & 24.432 & 23.016 & 22.917 \\
\hline
\end{tabular}

825

826

827

828

829

830

831

832

833

834

835

836

837

838 
Table 4. Overall Goodness-of-Fit of Confirmatory Factor Analysis

\begin{tabular}{|c|c|c|c|c|}
\hline \multirow{2}{*}{$\begin{array}{l}\text { Categories } \\
\text { of indicators }\end{array}$} & \multirow[b]{2}{*}{ Indicators } & \multirow[b]{2}{*}{ Fitness criteria } & \multicolumn{2}{|c|}{ Institutional Pressures } \\
\hline & & & Values & $\begin{array}{c}\text { Fitness } \\
\text { judgment }\end{array}$ \\
\hline \multirow{4}{*}{$\begin{array}{l}\text { Absolute } \\
\text { fit indicators }\end{array}$} & RMR & $<0.05$ & 0.018 & Yes \\
\hline & RMSEA & $<0.08$ & 0.064 & Yes \\
\hline & GFI & $>0.90$ & 0.953 & Yes \\
\hline & AGFI & $>0.90$ & 0.913 & Yes \\
\hline \multirow{4}{*}{$\begin{array}{l}\text { Incremental } \\
\text { fit indicators }\end{array}$} & NFI & $>0.90$ & 0.927 & Yes \\
\hline & IFI & $>0.90$ & 0.966 & Yes \\
\hline & TLI & $>0.90$ & 0.948 & Yes \\
\hline & CFI & $>0.90$ & 0.965 & Yes \\
\hline \multirow{6}{*}{$\begin{array}{l}\text { Parsimonious } \\
\text { fit indicators }\end{array}$} & PGFI & $>0.50$ & 0.508 & Yes \\
\hline & PNFI & $>0.50$ & 0.618 & Yes \\
\hline & PCFI & $>0.50$ & 0.643 & Yes \\
\hline & $\chi^{2} / \mathrm{DF}$ & $<2.00$ & 1.818 & Yes \\
\hline & \multirow[b]{2}{*}{ CAIC } & $\begin{array}{l}\text { Values of default model are } \\
\text { lower than those of independent } \\
\text { and saturated models }\end{array}$ & $\begin{array}{c}85.624<90.000 \\
85.624<618.505\end{array}$ & Yes \\
\hline & & $\begin{array}{l}\text { Values of default model are } \\
\text { lower than those of independent } \\
\text { and saturated models }\end{array}$ & $\begin{array}{l}175.678<282.972 \\
175.678<657.099\end{array}$ & Yes \\
\hline
\end{tabular}


Table 5. Measurement Validity and Construct Correlations.

\begin{tabular}{lllllllll}
\hline & & & & \multicolumn{6}{c}{ Correlation matrix } \\
\cline { 5 - 9 } Constructs & CR & Cronbach's $\alpha$ & AVE & CPs & MPs & NPs & OS & OCBEs \\
\hline CPs & 0.866 & 0.771 & 0.683 & $\mathbf{0 . 8 2 6}$ & & & & \\
MPs & 0.865 & 0.766 & 0.681 & 0.330 & $\mathbf{0 . 8 2 5}$ & & & \\
NPs & 0.880 & 0.795 & 0.710 & 0.296 & 0.442 & $\mathbf{0 . 8 4 3}$ & & \\
OS & 0.842 & 0.750 & 0.571 & 0.293 & 0.501 & 0.473 & $\mathbf{0 . 7 5 6}$ & \\
OCBEs & 0.927 & 0.908 & 0.646 & 0.302 & 0.552 & 0.525 & 0.529 & $\mathbf{0 . 8 0 4}$ \\
\hline
\end{tabular}

850

851

852

853

854

855

856

857

858

859

860

861

862

863

864

865

866

867

868

869

870

871

872

873

874

875

876

877

878 


\begin{tabular}{|c|c|c|c|c|c|}
\hline \multirow{2}{*}{ Code } & \multicolumn{5}{|c|}{ Item loadings } \\
\hline & CPs & MPs & NPs & OS & OCBEs \\
\hline CPs1 & 0.872 & 0.292 & 0.302 & 0.270 & 0.305 \\
\hline CPs2 & 0.791 & 0.194 & 0.213 & 0.212 & 0.196 \\
\hline CPs3 & 0.816 & 0.322 & 0.206 & 0.239 & 0.226 \\
\hline MPs1 & 0.314 & 0.835 & 0.277 & 0.384 & 0.431 \\
\hline MPs2 & 0.272 & 0.833 & 0.343 & 0.469 & 0.457 \\
\hline MPs3 & 0.233 & 0.808 & 0.469 & 0.383 & 0.476 \\
\hline NPs1 & 0.245 & 0.376 & 0.854 & 0.421 & 0.430 \\
\hline NPs2 & 0.291 & 0.314 & 0.862 & 0.399 & 0.465 \\
\hline NPs3 & 0.210 & 0.430 & 0.811 & 0.375 & 0.430 \\
\hline OS1 & 0.264 & 0.348 & 0.342 & 0.735 & 0.458 \\
\hline OS2 & 0.157 & 0.378 & 0.369 & 0.767 & 0.417 \\
\hline OS3 & 0.210 & 0.404 & 0.307 & 0.771 & 0.410 \\
\hline OS4 & 0.256 & 0.388 & 0.417 & 0.732 & 0.302 \\
\hline OCBEs1 & 0.172 & 0.383 & 0.362 & 0.413 & 0.774 \\
\hline OCBEs2 & 0.255 & 0.523 & 0.459 & 0.458 & 0.867 \\
\hline OCBEs3 & 0.301 & 0.416 & 0.407 & 0.484 & 0.761 \\
\hline OCBEs4 & 0.110 & 0.372 & 0.385 & 0.362 & 0.756 \\
\hline OCBEs 5 & 0.264 & 0.484 & 0.418 & 0.379 & 0.814 \\
\hline OCBEs6 & 0.314 & 0.487 & 0.460 & 0.473 & 0.838 \\
\hline OCBEs7 & 0.250 & 0.417 & 0.449 & 0.392 & 0.808 \\
\hline
\end{tabular}

880

881

882

883

884

885

886 
Table 7. Results of Hypotheses Testing

\begin{tabular}{lccc}
\hline \multicolumn{1}{c}{ Path } & Standardized path coefficient $(\beta)$ & T-value & Inference \\
\hline H1a: CPs $\rightarrow$ OS & 0.093 & 1.483 & Not supported \\
H1b: CPs $\rightarrow$ OCBEs & 0.056 & 1.074 & Not supported \\
H2a: MPs $\rightarrow$ OS & 0.340 & 5.190 & Supported \\
H2b: MPs $\rightarrow$ OCBEs & 0.297 & 4.393 & Supported \\
H3a: NPs $\rightarrow$ OS & 0.296 & 5.147 & Supported \\
H3b: NPs $\rightarrow$ OCBEs & 0.264 & 4.925 & Supported \\
H4a: OS $\rightarrow$ OCBEs & 0.239 & 4.178 & Supported \\
\hline
\end{tabular}

888

889

890

891

892

893

894

895

896

897

898

899

900

901

902

903

904

905

906

907

908

909

910

911

912

913

914

915 


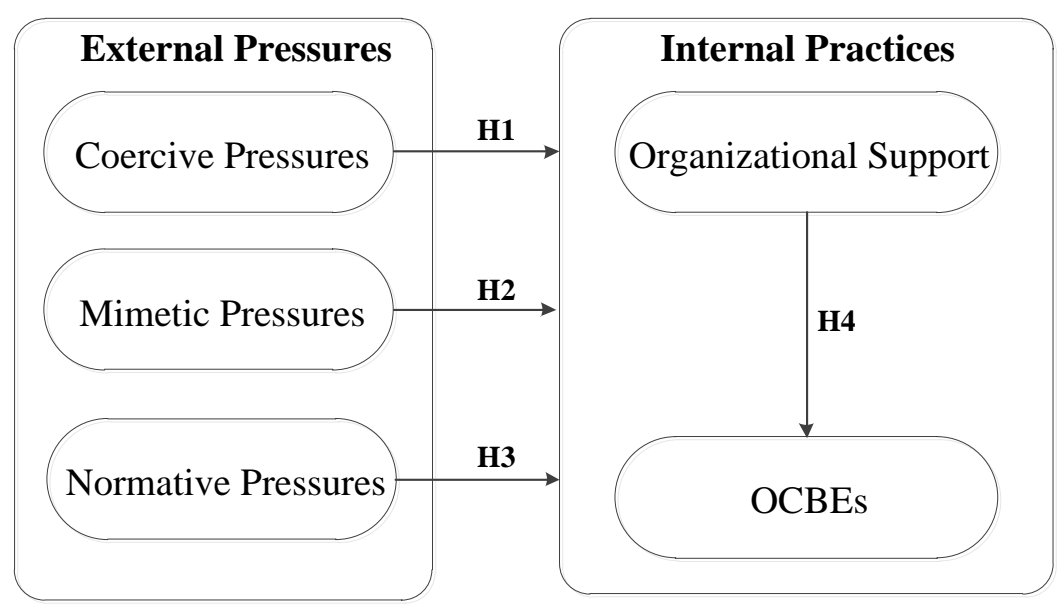

Fig.1. Research framework 


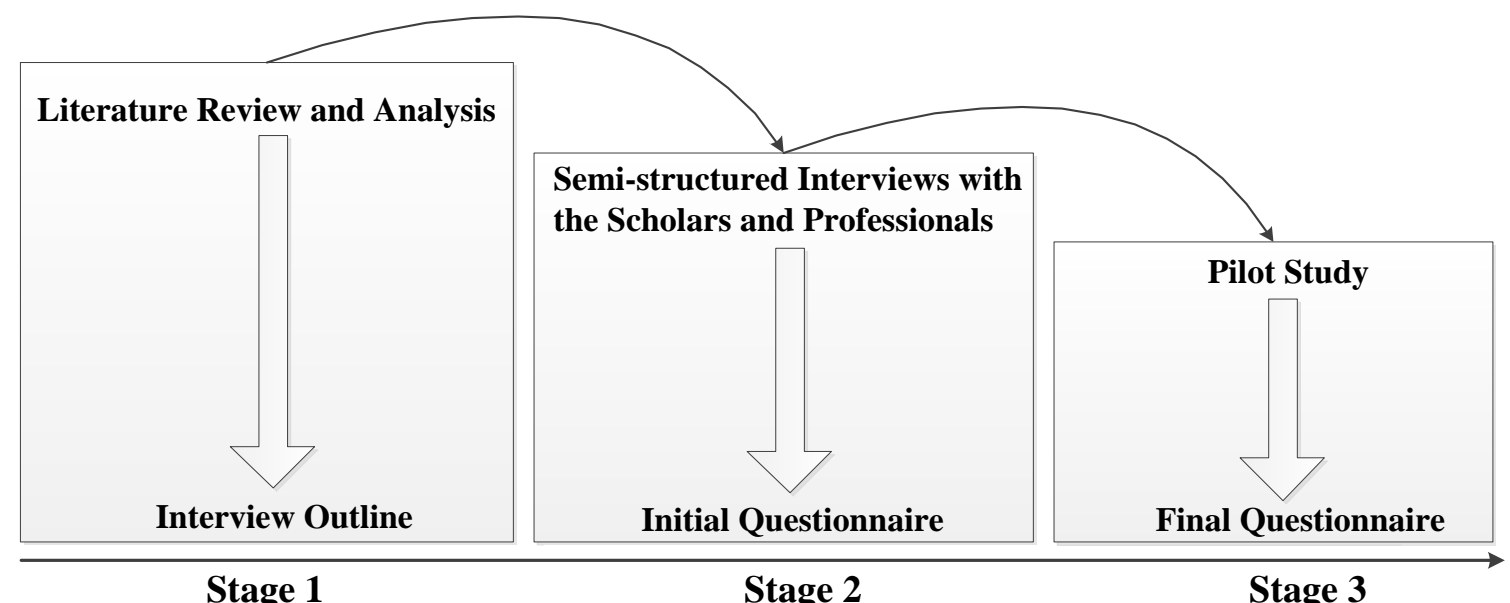

Stage 1

Stage 2

Stage 3

Fig.2. Flowchart of questionnaire development 


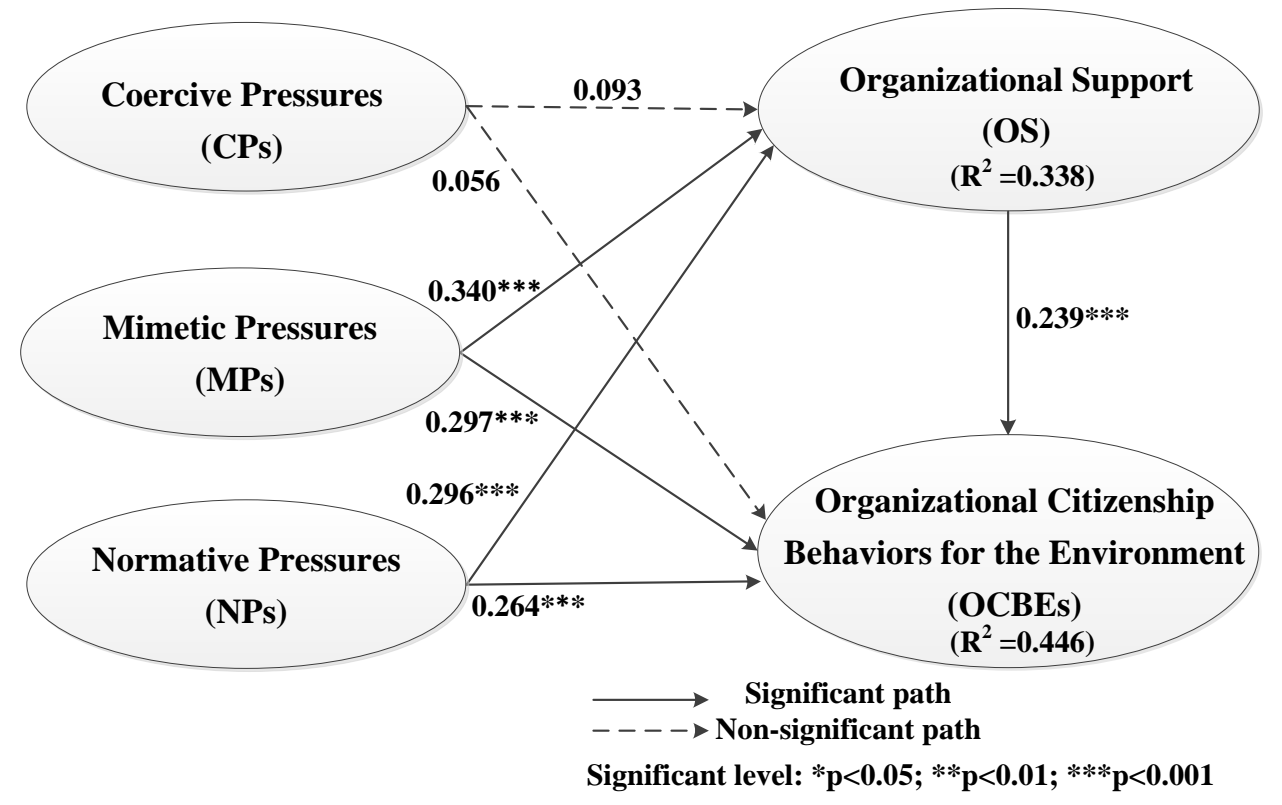

Fig. 3. Results of PLS analysis for the original research model 


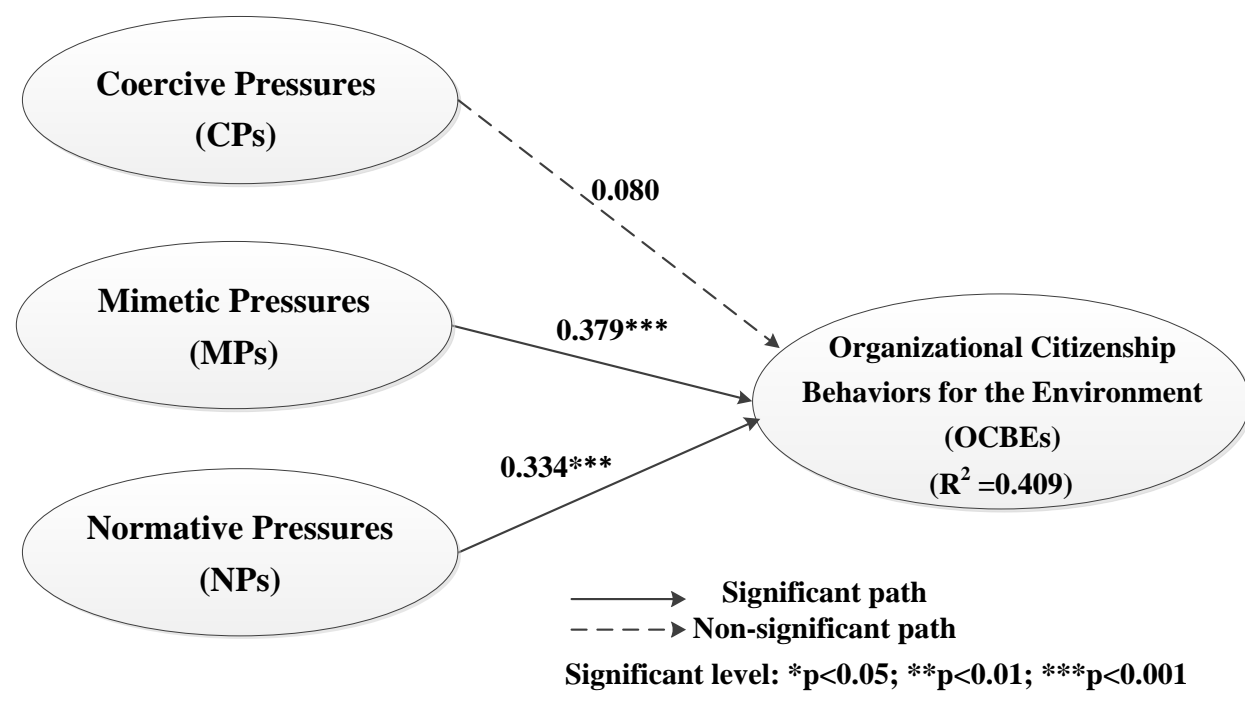

Fig. 4. Results of PLS analysis for the alternative research model 
Appendix S1. Measurement items in the questionnaire

\section{Coercive pressures (CPs)}

CPs1: Government attaches importance to project environmental protection;

CPs2: Industry association attaches importance to project environmental protection;

CPs3: Third-party environmental supervision attaches importance to project environmental protection.

\section{Mimetic pressures (MPs)}

MPs1: Many similar projects earn a reputation by effective environmental management; MPs2: Many similar projects achieve favorable effects in environmental practices;

MPs3: Peer project participants receive good recognition in environmental protection;

MPs4: Peer project participants all attach importance on environmental issues.

\section{Normative pressures (NPs)}

NPs1: Industry experts advise my project to attach importance on environmental issues;

NPs2: Consultant firms advise my project to attach importance on environmental issues;

NPs3: Academic communities advise my project to attach importance on environmental issues.

\section{Organizational support (OS)}

OS1: My project (manager) encourages environmental initiatives;

OS2: My project (manager) values inputs on environmental issues;

OS3: My project (manager) gives complete and accurate information regarding environmental issues;

OS4: My project (manager) provides a lot of opportunities to develop environmental skills.

5. Organizational citizenship behaviors for the environment (OCBEs)

OCBEs1: I suggest new practices that could improve the environmental performance of my project;

OCBEs2: I encourage my colleagues to adopt more environmentally conscious behaviors;

OCBEs3: I stay informed of my project’s environmental initiatives;

OCBEs4: I make suggestions about ways to protect the environment more effectively in my project; 
OCBEs5: I volunteer for programs or activities that address environmental issues in my project;

OCBEs6: Even when I am busy, I spontaneously give my time to help my colleagues take the environment into account;

OCBE7: I undertake environmental actions that contribute positively to my project's image and interest. 